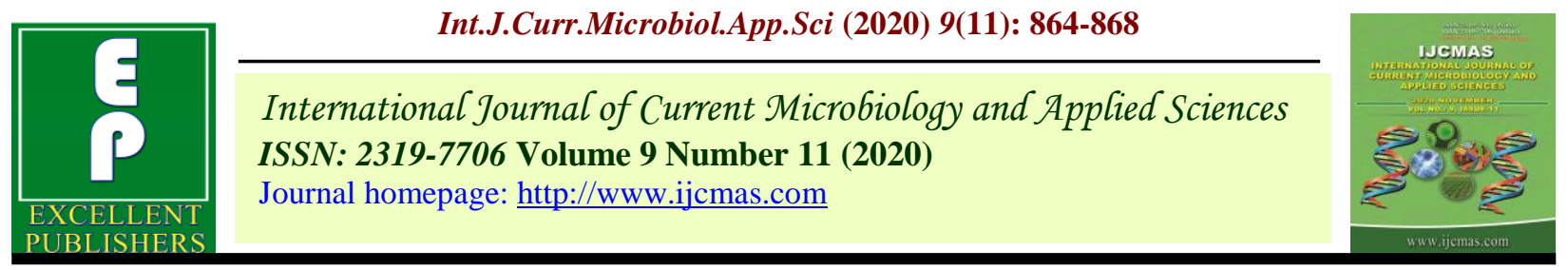

Original Research Article

https://doi.org/10.20546/ijcmas.2020.911.103

\title{
Studies on Physical Properties of Different Horse Gram Varieties Suitable for Machine Sowing
}

\author{
G. C. Jayashree* and P. N. Krishnamma \\ Department of Agricultural Engineering, College of Agricultural Engineering, University of \\ Agricultural Sciences, GKVK Campus, Bangalore, India \\ *Corresponding author
}

A B S T R A C T

\begin{tabular}{|l|}
\hline Ke y w or d s \\
$\begin{array}{l}\text { Horsegram, } \\
\text { Physical properties, } \\
\text { Bulk density, } \\
\text { Geometric } \\
\text { diameter, etc }\end{array}$ \\
\hline Article Info \\
\hline $\begin{array}{l}\text { Accepted: } \\
10 \text { October } 2020 \\
\text { Available Online: } \\
10 \text { November } 2020\end{array}$ \\
\hline
\end{tabular}

Physical properties of two different varieties of horse gram (Paiyur 1 and Paiyur 2) which are highly suitable for rainfed sowing were studied and the observations revealed that the mean data with standard error on physical parameters viz., bulk density, true density, length, breadth, thickness, surface area, geometric diameter, sphericity and 100 seed weight vary within the two varieties as $0.923 \mathrm{~g} \mathrm{~cm}^{-3}, 1306.8 \mathrm{Kg} \mathrm{m}^{-3}, 5.19 \mathrm{~mm}, 3.73 \mathrm{~mm}$, $2.21 \mathrm{~mm}, 7.86 \mathrm{~mm}^{2}, 3.49,67.26$ per cent and 4.92. Calibration of cup feed seed drill modified with the cup size of $6 \mathrm{~mm}$, which was derived based on the major and minor axis of the physical properties of horse gram seeds.

\section{Introduction}

Horse gram is an important crop of South India. Its grain is used for human consumption as 'dal' as well as in preparation of so called 'rasam' and also as a concentrated feed for cattle. It may also be used as green manure. This crop is generally grown when the cultivator is unable to sow any other crop for want of timely rains and also grown in vacant space of citrus orchard. Horse gram is mainly cultivated in the states of Karnataka, Andhra Pradesh, Tamil Nadu, Odisha, Madhya Pradesh, Chhattisgarh, Bihar, West Bengal, Jharkhand, and in foot hills of Uttaranchal and H.P., in India. Horse gram is an underutilized pulse crop grown in wide range of adverse climatic conditions. It occupies an important place in human nutrition and has rich source of protein, minerals, and vitamins. Horse gram (Macrotyloma uniflorum) is one such underutilized crop belonging to Fabaceae and well known for its hardiness, adaptability to poor soil and adverse climatic condition. The crop has good adaptability under adverse climate conditions. It yield well on poor soils, is drought resistant, has high nitrogen fixation ability and also helps in soil conservation (Yadava and Vyas, 1994). It is a cheapest 
source of protein and also rich in minerals such as calcium (Sawant et al., 2015). The production of horse gram was 1.24 lakh tonnes and 1.36 lakh tonnes and in Tamil Nadu during kharif and rabi season, the production was 0.10 lakh tonnes and 0.57 lakh tonnes during 2014-15 respectively (Tiwari and Shivhare, 2016). The horse gram was used to make various foods and traditional medicines due to its nutritional composition and also has a place in ayurvedic medicine (Bhuvaneswari et al., 2014). Horse gram has excellent therapeutic properties and traditionally used to cure kidney stones, asthma, bronchitis, leucoderma, urinary discharges, heart diseases, piles etc. Besides, it also possess anti-diabetic, anti-ulcer activity and also helps in dietary management of obesity due to the presence of beneficial bioactive compounds (Bhartiya et al., 2015). The fibre content of horse gram was high and it helps in reducing the body fat (Kamala, 2009). Study was carried out to assess the physical properties of horse gram seeds with the available leading variety to modify the cups in the existing seed drill for machine sowing to achieve high productive potentials as compared to locally cultivated practices broad casting under real farm situation.

\section{Climate requirement}

Horsegram is extremely drought-resistant crop. Moderately warm, dry climatic conditions are suitable for its optimum growth. It does not grow well on higher altitudes because of cool and wet climate. Horsegram can be cultivated up to an altitude of $1000 \mathrm{~m}$ above the sea level.

The temperature range of $25-30^{\circ} \mathrm{C}$ and relative humidity between 50 and $80 \%$ is optimum for its growth. Heavy rains during the initial stages of crop growth affect nodule formation owing to poor aeration in the soil. A well-distributed rainfall of about $800 \mathrm{~mm}$ is sufficient for its successful cultivation, but it performs well even under low rainfall areas.

\section{Materials and Methods}

\section{Evaluation of physical properties of horse gram seeds}

In the present study, the existing cup feed seed drill used for multiple crops were taken to modify the cup size for horse gram seeds. To modify or to alter the cups in the existing seed drill, the physical characters of horsegram were studied with two different varieties, Paiyur 1 and Paiyur 2 which are highly suitable for rainfed sowing were selected as shown in Fig. 1. The bulk seeds of horse gram were cleaned to remove foreign matter, broken and immature seeds. The physical properties of horsegram viz., hundred-grain weight, projected area, bulk density, porosity, sphericity, size and shape were evaluated with of each of the varieties, as the size of grains represented by their equivalent diameter and sphericity is used to describe their shape and the surface area, which is calculated as the projected area (Asoegwu et al., 2006).

\section{Bulk density}

Horse gram seeds (Paiyur 1 \& Paiyur 2) were taken in containers of cubical and cylindrical shape. The volume of the containers is found by measuring length, breadth and height for cubical container and by measuring diameter and height for cylindrical container. The bulk density of the seeds was found separately as follows.

$$
\text { Bulk density }=\frac{\text { Weight of grain }(\mathrm{g})}{\text { Volume of grain }\left(\mathrm{cm}^{3}\right)}
$$

\section{True density}

Known volume of water is taken in a measuring cylinder and ' $N$ ' numbers of grains of uniform size are taken, weighed and the 
true density was calculated as follows:

True density $=\frac{\text { Weight of grain }(\mathrm{g})}{\text { Volume of grain }\left(\mathrm{cm}^{3}\right) \text { Exclude the voids of grain }}$

\section{Size}

The size was determined by measuring the dimension of the principal axes viz., major, intermediate and minor diameters of 100 randomly selected horse gram seeds using micro meter having a sensitivity of $0.01 \mathrm{~mm}$ (0-25 mm) as length, breadth and thickness.

\section{Geometric mean diameter}

The geometric mean diameter (Dg) was calculated using the following equation (Olajide and Igbeka, 2003):

$\mathrm{Dg}=\mathrm{LWT}^{0.333}$

\section{Sphericity $(\varnothing)$}

The sphericity was calculated using the following equations as per (Olajide and Igbeka, 2003).

$\varnothing=\frac{L_{W T} T^{0.333}}{L}$

where: $\mathrm{L}$ is the major diameter; $\mathrm{W}$ is the intermediate diameter and $\mathrm{T}$ is the minor diameter.

\section{Surface area}

The surface area of the horse gram is determined by drawing the outline of the 50 numbers randomly selected seeds in graph sheet with the box size of $1 \mathrm{~mm}^{2}$. The geometrical parameters namely length $(\mathrm{L}$ is the major diameter; $\mathrm{W}$ is the intermediate diameter and $\mathrm{T}$ is the minor diameter), surface area were measured. The surface area was used to calculate the projected area.

\section{Hundred-seed weight}

Hundred seeds in eight replications were selected from the Paiyur 1 and Paiyur 2 variety and weighed in a sensitive electronic balance of $0.001 \mathrm{~g}$ as per the procedure given by ISTA rules (ISTA, 2013).

\section{Shape}

By visual observation the shape was classified based on length and breadth as oval/spherical /round /oval etc.

\section{Results and Discussion}

\section{Seed properties of horse gram varieties}

The physical properties of horsegram viz., hundred-grain weight, projected area, bulk density, porosity, sphericity, size and shape (Table 1).

The observations revealed that the mean data with standard error on physical parameters viz., bulk density, true density, length, breadth, thickness, surface area, geometric diameter, sphericity and 100 seed weight vary within the two varieties as $0.923 \mathrm{~g} \mathrm{~cm}^{-3}$, $1306.8 \mathrm{Kg} \mathrm{m}^{-3}, 5.19 \mathrm{~mm}, 3.73 \mathrm{~mm}, 2.21 \mathrm{~mm}$, $7.86 \mathrm{~mm}^{2}, 3.49,67.26$ per cent and 4.92 .

\section{Calibration of cups of the seed drill for} horsegram

Based on the results of physical parameters for the horse gram cv. Paiyur 1 and Paiyur 2, it was found that the hole diameter of the cups to be reduced from 10 to $6 \mathrm{~mm}$ to accommodate the both the Paiyur 1and Paiyur 2 seed varieties. Hence a little modification was made to reduce the cup holes diameter from 10 to $6 \mathrm{~mm}$ by applying the M-seal in the cup holes shown in Fig. 2. After the modification of cup holes again the calibration is done to calculate the seed rate. 
Table.1 Physical properties of Horse gram seeds

\begin{tabular}{|c|c|c|c|}
\hline \multirow[t]{2}{*}{ Physical properties } & \multicolumn{2}{|c|}{ Horsegram varieties } & \multirow[t]{2}{*}{ Mean } \\
\hline & Paiyur 1 & Paiyur 2 & \\
\hline Bulk density & $0.921 \mathrm{~g} \mathrm{~cm}^{-3}$ & $0.924 \mathrm{~g} \mathrm{~cm}^{-3}$ & $0.923 \mathrm{~g} \mathrm{~cm}^{-3}$ \\
\hline Standard error & 0.003 & 0.002 & 0.003 \\
\hline $95 \%$ confidence limit & $0.921 \pm 0.0007$ & $0.924 \pm 0.0004$ & $0.923 \pm 0.0008$ \\
\hline True density & $1272.2 \mathrm{Kg} \mathrm{m}^{-3}$ & $1341.3 \mathrm{Kg} \mathrm{m}^{-3}$ & $1306.8 \mathrm{Kg} \mathrm{m}^{-3}$ \\
\hline Standard error & 0.38 & 0.53 & 0.46 \\
\hline $95 \%$ confidence limit & $1272.2 \pm 0.76$ & $1341.3 \pm 1.06$ & $1306.8 \pm 34.6$ \\
\hline \multicolumn{4}{|l|}{ Size } \\
\hline Length ( mm) & 5.17 & 5.20 & 5.19 \\
\hline Standard error & 0.042 & 0.033 & 0.38 \\
\hline $95 \%$ confidence limit & $5.17 \pm 0.08$ & $5.20 \pm 0.07$ & $5.19 \pm 0.01$ \\
\hline Width ( mm) & 3.82 & 3.63 & 3.73 \\
\hline Standard error & 0.047 & 0.040 & 0.44 \\
\hline $95 \%$ confidence limit & $3.82 \pm 0.09$ & $3.63 \pm 0.08$ & $3.73 \pm 0.09$ \\
\hline Thickness (mm) & 2.20 & 2.21 & 2.21 \\
\hline Standard error & 0.015 & 0.017 & 0.016 \\
\hline $95 \%$ confidence limit & $2.20 \pm 0.03$ & $2.21 \pm 0.03$ & $2.21 \pm 0.03$ \\
\hline Surface Area $\left(\mathrm{mm}^{2}\right)$ & 8.38 & 7.25 & 7.86 \\
\hline Standard error & 1.751 & 1.642 & 1.697 \\
\hline $95 \%$ confidence limit & $8.38 \pm 3.50$ & $7.25 \pm 3.28$ & $7.86 \pm 3.50$ \\
\hline Geometric diameter & 3.51 & 3.46 & 3.49 \\
\hline Standard error & 0.195 & 0.192 & 0.193 \\
\hline $95 \%$ confidence limit & $3.51 \pm 0.390$ & $3.46 \pm 0.385$ & $3.46 \pm 0.385$ \\
\hline Sphericity (\%) & 67.91 & 66.60 & 67.26 \\
\hline Standard error & 0.040 & 0.039 & 0.040 \\
\hline $95 \%$ confidence limit & $67.91 \pm 0.08$ & $66.60 \pm 0.079$ & $67.26 \pm 0.0791$ \\
\hline 100 grain weight (g) & 4.97 & 4.87 & 4.92 \\
\hline Standard error & 0.001 & 0.002 & 0.002 \\
\hline $95 \%$ confidence limit & $4.97 \pm 0.003$ & $4.87 \pm 0.005$ & $4.92 \pm 0.005$ \\
\hline Shape & Oval & Oval & Oval \\
\hline
\end{tabular}

Fig.1 Varieties selected for measuring the physical properties
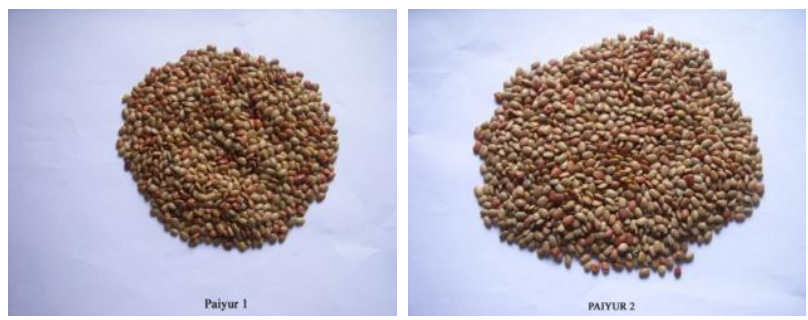
Fig.2 View of the cup hole size

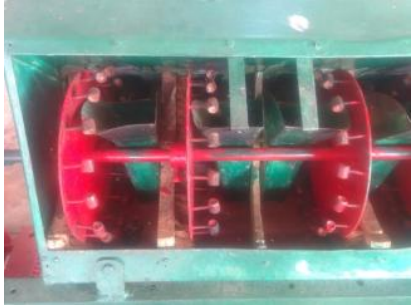

Existing cups

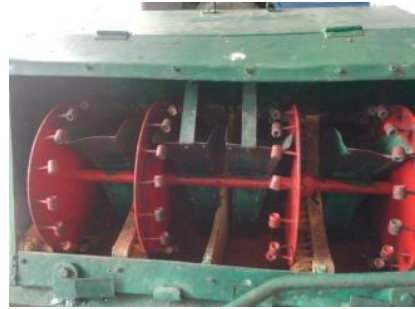

Modified cups
From the calibration it is observed that each cup picks around 6 numbers of seeds from the hopper and the same was dropped to the funnel for sowing. around $11.07 \mathrm{~kg} \mathrm{ha}^{-1}$ of seed will be used for sowing in the field when using this modified cup feed seed drill, which was $9 \mathrm{~kg}$ lesser than actual recommended seed rate for sowing horse gram which is $20 \mathrm{~kg} \mathrm{ha}^{-1}$ as per Crop Protection Guide, (2012).

In conclusions the physical parameters between varieties did not differ widely the mean physical parameters are measured as $0.923 \mathrm{~g} \mathrm{~cm}^{-3}, 1306.8 \mathrm{Kg} \mathrm{m}^{-3}, 5.19 \mathrm{~mm}$, $3.73 \mathrm{~mm}, 2.21 \mathrm{~mm}, 7.86 \mathrm{~mm}^{2}, 3.49$, 67.26 per cent and 4.92. Based on the above parameters the holes of the existing seed drill was modified $10 \mathrm{~mm}$ to $6 \mathrm{~mm}$ by applying the Mseal, which reduced the seed rate as 11.07 kg/ha (Anon, 2012).

\section{References}

Anon 2012, Crop Protection guide, Tamil Nadu Agricultural University, Coimbatore
Bhartiya JP, Aditya, Kant L. Nutritional and Remedial Potential of an Underutilized Food Legume Horsegram (Macrotyloma uniflorum): A Review. The Journal of Animal \& Plant Sciences. 2015; 25(4):908-920.

Bhuvaneshwari S. Influence of Dolichos biflorus on body weight in obese humans. International Journal of Pharmaceutical \& Biological Archive. 2014; 13:5-1.

Sawant AA, Thakor NJ, DhekaleJS. Application of Horse Gram Flour In Extruded Products. International Journal of Development Research, 2015, 5(10).

Tiwari AK, Shivhare AK. Pulses In India: Retrospect And Prospects. Director, Govt. of India, Ministry of Agri. \& Farmers Welfare (DAC\&FW). 2016, $1(2)$.

Kamala. 2009. http://www.cookatease. com/kolluhorsegram-masiya

Yadav, N.D., and Vyas, N.L.1994. Arid legumes. Agro publishers. India pp 6478

\section{How to cite this article:}

Jayashree, G. C. and Krishnamma, P. N. 2020. Studies on Physical Properties of Different Horse Gram Varieties Suitable for Machine Sowing. Int.J.Curr.Microbiol.App.Sci. 9(11): 864868. doi: https://doi.org/10.20546/ijcmas.2020.911.103 